\title{
NTN1 wt Allele
}

National Cancer Institute

\section{Source}

National Cancer Institute. NTN1 wt Allele. NCI Thesaurus. Code C54371.

Human NTN1 wild-type allele is located within 17p13-p12 and is approximately $218 \mathrm{~kb}$ in length. This allele, which encodes netrin-1 protein, is involved in the modulation of axonal outgrowth. 